\title{
Sosialisasi Penggunaan Media Big Book dalam Penerapan Membaca Permulaan dan Peningkatan Kosakata Siswa
}

\author{
Hermariyanti Kusumadewi, Reknosari \\ Universitas Indraprasta PGRI \\ Email: khermariyanti@gmail.com
}

\begin{abstract}
Abstrak
Media pembelajaran big book dapat dijadikan pilihan dalam menumbuhkan minat baca anak usia dini. Dalam big book, anak tidak hanya bisa melihat gambar yang penuh warna tetapi juga bisa membaca tanpa ada perasaan bosan dengan materi bacaan yang dibaca. Membaca tidak melulu membaca huruf tapi dapat diawali dengan membaca gambar dan dilanjutkan dengan membaca huruf dan kalimat. melalui kebiasaan yang dilakukan secara rutin oleh orang tua, diharapkan membaca bukan lagi hal yang menakutkan namun menjadi hal yang menyenangkan. Big book bisa dibuat bersama dengan anak dengan bermodalkan alat dan bahan yang sederhana. Lewat media big book, orang tua bisa mengkombinasikannya dengan kegiatan menggambar dan mewarnai. Lalu dilanjutkan dengan mengenalkan huruf lewat kalimat sederhana yang singkat dan mudah. Untuk itu pada kesempatan kali ini tim tertarik untuk melakukan kegiatan Pengabdian Kepada Masyarakat pada Orang tua Siswa SDN Pagelaran 04. Kegiatan ini bertujuan untuk memberikan sosialisasi tentang media pembelajaran big book dan memberikan edukasi kepada para orang tua bagaimana mengasah keterampilan membaca permulaan dan meningkatkan kosakata siswa.
\end{abstract}

Kata Kunci: Media Big Book, Membaca Permulaan, Kosakata

\begin{abstract}
Media of learning a big book can be used as an option in fostering reading interest in early childhood. In a big book, children can not only see colorful pictures but also read without feeling bored with the reading material they are reading. Reading is not just reading letters but can be started by reading pictures and then reading letters and sentences. Through habits carried out routinely by parents, it is hoped that reading is no longer a scary thing but a fun thing. Big books can be made together with children using simple tools and materials. Through the big book media, parents can combine it with drawing and coloring activities. Then proceed with introducing letters through simple, short and easy sentences. For this reason, on this occasion the team is interested in carrying out Community Service activities for Parents of SDN Pagelaran 04 students. This activity aims to provide socialization about the media of learning Big book and providing education to parents how to hone early reading skills and improve student vocabulary.
\end{abstract}

Keywords: Big book Media, Beginning Reading, Vocabulary 


\section{PENDAHULUAN}

Peran orang tua dalam mencetak generasi yang berprestasi dan berakhlak mulia sangat penting. Melalui orang tua, anak mulai belajar mendengar, berbicara dan meniru hal yang dilakukan orang tua. Rumah sebagai tempat belajar awal anak dalam membentuk sikap dan karakter anak di masa depan. Komunikasi yang baik antara anak dan orang tua menjadi hal penting demi terbentuknya generasi masa depan yang berkualitas. Mendidik anak sejak dini memang perlu melibatkan masyarakat umum bukan sekedar menjadi tugas orang tua semata. Sikap orang tua saat mendaftarkan anak-anaknya untuk sekolah perlu diperhatikan. Jangan karena tren sekolah dini membuat orang tua gengsi apabila tidak menyekolahkan anaknya sebelum usianya empat tahun. Padahal banyak hal yang harus diperhatikan sebelum mendaftarkan anak ke sekolah formal maupun informal.

Dikutip dari Sahabat Keluarga Kementerian Pendidikan dan Kebudayaan (Kemendikbud) bahwa ada 4 alasan mengapa usia masuk SD ditetapkan 7 tahun minimal 6 tahun; 1) Aspek fisik, pada usia 7 tahun, gerakan motorik anak sudah lebih bagus, otot dan sarafnya juga sudah terbentuk sehingga dianggap paling siap secara fisik untuk diam di kelas sampai siang, dalam hal memegang pensil pun sudah lebih mampu jika harus menulis sendiri tanpa bantuan orang dewasa, 2) Aspek Psikologis, anak mulai bisa berkonsentrasi dengan baik pada usia di atas 6 tahun. Rentang konsentrasi untuk usia sekolah biasanya sekitar 30-45 menit. Dengan semakin bertambah usia anak, kemampuan konsentrasi juga meningkat, 3) Aspek Kognitif, mampu membaca, menulis, berhitung sederhana diharapkan saat akan masuk ke SD. Selain itu anak juga diharapkan mampu mengikuti instruksi, paham dan bisa mengerjakan soal-soal yang diberikan oleh guru, 4) Aspek emosi, anak terlalu dini masuk SD memang cukup matang secara akademik, namun biasanya kematangan emosi dan kemandiriannya belum maksimal. Padahal di jenjang SD anak tidak lagi akan mendapat perhatian seperti di TK.

Rendahnya minat dan kemampuan membaca di Indonesia menjadi salah satu alasan utama bagi orang tua untuk mengajarkan membaca sejak usia dini. Melalui kebiasaan yang dilakukan secara rutin, anak usia dini bisa belajar mengenal huruf dan kalimat sehingga ketika masuk usia sekolah, mereka sudah bisa membaca dengan baik.

Membaca pada usia dini bukan hal yang tidak mungkin. Melalui latihan membaca gambar, membaca huruf dan dilanjutkan pada membaca kalimat bukan tidak mungkin anak usia dini dapat menjadikan membaca sebagai hobinya kelak. Memperkenalkan membaca sedari dini berarti kita ikut memberantas buta huruf dan aksara. Selain itu juga mendukung program pemerintah dalam gerakan literasi nasional. Banyak media pembelajaran yang dapat dijadikan alat untuk mengasah kemampuan membaca seseorang. Mendidik anak di rumah dapat menggunakan cara-cara kreatif yang menstimulasi si anak dengan mencari alat stimulasi yang mudah untuk berkomunikasi dengan cara unik, lucu, dan menarik bagi anak.

Media pembelajaran big book dapat menjadi salah satu pilihan dalam meningkatkan minat baca anak sedari dini. Big book dapat dibuat sendiri dengan menggunakan alat dan bahan sederhana yang mudah didapat. Dengan big book, orang tua dapat mengajak si anak untuk menggambar, mewarnai gambar dan memperkenalkan huruf dan kalimat yang singkat dan sederhana dalam rangka memotivasi anak membaca. 
Melihat permasalahan yang ada di lapangan, tim tergerak untuk melakukan sebuah kegiatan pengabdian masyarakat dengan judul Sosialisasi Media big book dalam Penerapan Membaca Permulaan dan Peningkatan Kosakata siswa pada Orang Tua Siswa SDN Pagelaran 04 Bogor.

Melalui sosialisasi yang dilakukan oleh tim, diharapkan peran serta orangtua dan guru dalam memberantas buta aksara dan meningkatkan kebiasaan membaca dapat rutin dilakukan setiap hari. Sehingga program pemerintah untuk menumbuhkan minat baca dapat tercapai dan para generasi muda Indonesia siap bersaing dan berkompetisi dengan bangsa lain di kancah dunia dan mengharumkan nama bangsa.

\section{METODE}

Kegiatan Sosialisasi Media big book dalam Penerapan Membaca Permulaan dan Peningkatan Kosakata siswa pada Orang Tua Siswa SDN Pagelaran 04 Bogor dilakukan dengan metode penyuluhan. Peserta yang hadir dan menjadi sasaran sosialisasi ini adalah orangtua murid SDN Pagelaran 04 Bogor. Penyuluhan dilakukan pada hari Senin, 10 November 2019 dengan mempertimbangkan fasilitas pendukung kegiatan, tempat pelaksanaan untuk praktik para peserta penyuluhan, lokasi yang cukup strategis, keterbatasan waktu, tenaga dan pikiran para peserta dan pemateri.

\section{HASIL DAN DISKUSI}

Kegiatan Pengabdian Pada Masyarakat ini dilaksanakan dalam bentuk sosialisasi dan pelatihan terprogram. Sosialisasi Penerapan Media big book dalam Penerapan Membaca Permulaan dan Peningkatan Kosakata siswa diperuntukkan untuk Orang Tua Siswa SDN Pagelaran 04 Bogor yang dilaksanakan pada hari senin tanggal 10 November 2019. Terdapat 20 orang tua murid ikut berpartisipasi dalam kegiatan penyuluhan.

Dari kegiatan penyuluhan yang dilaksanakan oleh tim, para orangtua murid SDN Pagelaran 04, Bogor menjadi tahu tentang teori dan konsep membaca permulaan dan peningkatan kosakata bahasa anak. Selain itu, Kelompok abdimas juga menjelaskan teori dan konsep media big book dan menjelaskan langkah-langkah penerapan membaca permulaan dan peningkatan kosakata bahasa siswa dengan menggunakan media big book.

Penerapan penyuluhan ini terbagi dalam 4 tahapan. Pada tahap awal kegiatan, peserta dikenalkan pada teori, konsep, dan tujuan pembelajaran membaca permulaan dan kosakata bahasa siswa, setelah itu diberikan pengertian mengenai konsep berbagai media yang dapat mendukung kegiatan pembelajaran bahasa. Lalu setelah mereka siap untuk mendapatkan materi mengenai media pembelajaran, kami selaku pemateri menyajikan slide materi mengenai penjelasan media Bigbook. Peserta menyimak dengan serius dan membaca secara seksama materi yang sudah diberikan sebelumnya. Setelah menjelaskan definisi dan teori - teori mengenai penerapan media Bigbook dalam membaca permulaan dan kosakata siswa, Tim abdimas mulai menjelaskan kegunaan dan langkah-langkah penerapan media Bigbook. Pada sesi praktek, setiap peserta menyiapkan alat dan bahan untuk membuat media Bigbook yang sudah dipersiapkan terlebih dahulu oleh Tim abdimas, adapun alat dan bahan yan sudah dipersiapkan 
adalah kertas bergambar, kertas gambar/hvs, guntung, lem, dan spidol. Sesuai arahan tim badimas peserta mencoba membuat media Bigbook dengan kreatifitas masing-masing

\section{KESIMPULAN DAN SARAN}

Kesimpulan dari kegiatan Sosialisasi Penerapan Media big book dalam Penerapan Membaca Permulaan dan Peningkatan Kosakata siswa diperuntukkan untuk Orang Tua Siswa SDN Pagelaran 04 Bogor membuat para orangtua yang tadinya cuek dan kurang aktif dalam menemani anaknya belajar di rumah, setelah penyuluhan ini, mereka menjadi lebih aktif dan banyak meluangkan waktu bagi anak-anaknya dalam mendampingi anak belajar di rumah, terutama dalam hal membaca.

Demi keberlanjutan dan manfaat di masa sekarang dan masa yang akan datang, para guru dan orangtua murid terutama di SDN Pagelaran 04 Bogor bisa lebih sering mendapatkan penyuluhan semacam ini lebih sering guna menambah pengetahuan para orangtua dalam hal mendidik anak dan bagi para guru mempunyai wacana baru untuk banyak berkreasi menggunakan media pembelajaran yang lebih menarik dan menyenangkan.

\section{UCAPAN TERIMA KASIH}

Dengan restu Allah SWT, Alhamdulillah program pengabdian kepada masyarakat yang berjudul Sosialisasi Penerapan Media big book dalam Penerapan Membaca Permulaan dan Peningkatan Kosakata siswa diperuntukkan untuk Orang Tua Siswa SDN Pagelaran 04 Bogor berjalan dengan sukses. Hal ini dapat terselenggara dengan baik karena peran serta banyak pihak. Kami mengucapkan terimakasih kepada 1) LPPM Universitas Indraprasta PGRI yang telah memberi bantuan materi maupun non materi, 2) Kepala SDN Pagelaran 04 Bogor beserta para guru dan para orangtua murid yang telah memberi kesempatan untuk menjadi mitra kami dalam terselenggaranya kegiatan penyuluhan ini, dan 3) rekan tim abdimas yang sangat kooperatif dan saling mendukung sehingga kegiatan ini terselenggara dengan baik dan sukses.

\section{DAFTAR PUSTAKA}

Dardjowidjojo, S. 2005. Psikolinguistik: Pengantar Pemahaman Bahasa Manusia. Jakarta: Yayasan Obor Indonesia.

Morrison, GS. 2012. Dasar - Dasar Pendidikan anak Usia Dini (PAUD). Jakarta: Indeks.

Musfiroh, Tadkiroatun. 2008. Cerdas Melalui Bermain. Jakarta: Grasindo.

Seefeldt, Carol dan Barbara A. Wasik. 2008. Pendidikan anak Usia Dini: Menyiapkan Anak Usia Tiga, Empat, dan Lima Tahun Masuk Sekolah. Jakarta: Indeks.

Tarigan, H.G., (2008). Membaca Sebagai Suatu Keterampilan Berbahasa. Bandung: Penerbit Angkasa

Tim USAID. (2014). Buku Sumber untuk Dosen LPTK, Pembelajaran Literasi Awal di LPTK. USAID

\section{Internet:}

https://pustakapaud.blogspot.com/2016/08/pengertian-metode-membaca-permulaan-padaanak-usia-dini.html?m=1 (diakses 18 Januari 2019 pukul 14:00) 
http://www.prioritaspendidikan.org/penggunaan-big-book-dalam-pembelajaranbahasa.html?m=1 (diakses 18 Januari 2019 pukul 14:00) 